\title{
Phenotypic and genome size changes (variation) in synthetic tetraploids of daylily (Hemerocallis) in relation to their diploid counterparts
}

\author{
M. Podwyszyńska $\cdot$ E. Gabryszewska • \\ B. Dyki • A. A. Stępowska • A. Kowalski • \\ A. Jasiński
}

Received: 18 March 2014/ Accepted: 9 July 2014/Published online: 24 July 2014

(C) The Author(s) 2014. This article is published with open access at Springerlink.com

\begin{abstract}
Tetraploids of daylily have taken a leading position among the daylily cultivars due to desirable traits such as vigorous growth and flowers with more intense colour. In our previous studies, several tetraploids of daylily cultivars 'Blink of an Eye' and 'Berlin Multi' were obtained using in vitro techniques with different antimitotic agents (colchicine, oryzalin, trifluralin, and amiprophos methyl). The purposes of this study were to evaluate changes in daylily tetraploids in relation to their diploid counterparts and to assess variation among diploids and tetraploids derived from genetically homogenous plant material treated with antimitotic agents. In the first year of the ex vitro cultivation, growth of tetraploids was poorer in comparison with diploids, but in the second year, tetraploid growth was much more vigorous. Compared to diploids, in tetraploids of both cultivars percentage of flowering plants was lower, flowering was delayed by 8 days and 1 month in 'Blink of an Eye' and 'Berlin Multi', respectively, and bud number per scape was lower by approximately 20 and $40 \%$, respectively. Tetraploid leaves and flowers of both cultivars were significantly larger, chlorophyll concentration
\end{abstract}

M. Podwyszyńska ( $₫)$ · E. Gabryszewska ·

B. Dyki · A. A. Stępowska · A. Kowalski

Research Institute of Horticulture, Konstytucji 3 Maja 1/3,

96-100 Skierniewice, Poland

e-mail: Malgorzata.Podwyszynska@inhort.pl

A. Jasiński

Horticulture, Wierzbowa 1, 05-820 Piastów, Poland index was higher by approximately $40 \%$, and stomata were longer by $35 \%$. In 'Berlin Multi' tetraploids, inflorescence stems were shorter by $20 \%$. In 'Blink of an Eye', variation in flower colour tone and shape and stamen malformation rate was detected both within the unconverted diploids and tetraploids but was more evident in tetraploids. In both cultivars, variation was also found in the nuclear DNA content, which ranged in diploids and tetraploids, respectively, 8.02-8.53 and 16.01-17.13 pg in 'Berlin Multi' and 8.28-8.71 and 15.93-17.36 pg in 'Blink of an Eye'. Since the variation, while less evident, also occurred in the diploids (regenerated from the antimitotic treated material), we suppose that these variations could be due to antimitotic agents that can induce not only chromosome doubling but also chromosomal and gene mutations. The extent and character of these changes can be related to parental genotype and/or antimitotic agent. Further research is required at the cytological and molecular level to explain the character of changes, epigenetic and/or genetic.

Keywords Chromosome doubling · In vitro · Hemerocallis · Phenotype variation · Nuclear DNA content

\section{Introduction}

Daylilies (Hemerocallis) are very valuable garden perennials that are resistant to unfavourable conditions 
such as light or water deficiency. Currently in daylily, the polyploid cultivars are in high demand (Gulia et al. 2009; Zhang et al. 2013). In general, polyploids, especially triploids and tetraploids, are widely used in the breeding programs of many crops including ornamental plant species (Scott et al. 2013). Polyploids often show novel phenotypes compared with their diploid counterparts (Chen 2007; Rogalska et al. 2007). Some of these traits are superior to their diploid progenitors (e.g., vigorous growth or large organs). Polyploids are classified in two major categories: alloand autopolyploids (Ramanna and Jacobsen 2003; Rogalska et al. 2007). Allopolyploids contain genomes from divergent species and are obtained by hybridization followed by polyploidisation. Autopolyploids contain the multiplied genomes of the same species. There are two strategies of synthetic polyploid induction: meiotic (less frequently used in breeding) and mitotic. In meiotic (sexual) polyploidisation, $2 n$ gametes are induced (usually $2 n$ pollen) by arresting the mitotic process. $2 n$ pollen (induced with nitrous oxide gas) has recently been used for crossing with diploid cultivars in order to obtain triploids of tulip, lily, and begonia (Okazaki et al. 2005; BarbaGonzalez et al. 2006; Dewitte et al. 2010). The natural sexual polyploids (mainly triploids) that originate through the functioning of $2 n$ gametes (produced by almost all species in some frequencies) have been considered an important factor in flowering plant evolution (Osborn et al. 2003; Ramanna and Jacobsen 2003; Younis et al. 2014). The importance of sexual polyploidisation and potential to use its for crop improvement was widely described by Ramanna and Jacobsen (2003). However, due to irregular meiosis, triploids are usually infertile or less fertile than tetraploids. Also in daylily, triploids reportedly are less fertile than tetraploids and therefore, many breeders are interested in obtaining daylily tetraploids (Gulia et al. 2009).

In mitotic polyploidisation, chromosome doubling occurs in somatic cells. This type of chromosome doubling is widely applied for inducing tetraploids by the means of chemical antimitotic agents that interfere with functioning of microtubules inhibiting mitosis during metaphase. Within antimitotic agents, colchicine is utilised most commonly (Rogalska et al. 2007; Dhooghe et al. 2011). However, several authors reported that the use of this chemical caused frequent formation of mixoploids (Arisumi 1972; Chalak and
Legave 1996; Väinölä 2000; Carvalho et al. 2005). Moreover, due to the strong action of colchicine on the mammalian microtubuli, including human ones, this substance possesses carcinogenic effects (Morejohn and Fosket 1984). Therefore, other antimitotic agents, such as oryzalin, trifluralin, and amiprophos methyl (APM) have been used more frequently (Van Tuyl et al. 1992; Petersen et al. 2003; Dhooghe et al. 2009a, b; Podwyszyńska et al. 2010; Dewitte et al. 2010; Podwyszyńska 2011). These chemicals are the active ingredients of herbicides, and they are considered less toxic to human health.

Polyploidy causes immediate phenotypic changes (e.g., the increased nuclei, cell, and stomata sizes) (Stupar et al. 2007; Anssour et al. 2009). Other new morphological, physiological, or phenological characteristics often advantageous that can occur in tetraploids are as follows: larger leaves, flowers, fruits, roots, tubers, and bulbs; often greater vigor and biomass; increased disease/pest resistance; enhanced tolerance to drought or higher content of effective substances; improved post-harvest quality; and altered flowering time (Dhooghe et al. 2011). It is well documented that polyploidisation leads to novel phenotypes through alteration of dosage-regulated gene expression, altered regulatory interactions, and/ or rapid genetic and epigenetic changes (Osborn et al. 2003; Chen 2007; Rogalska et al. 2007; Parisod et al. 2010). Thus, polyploidy is considered an important source of novel variation. Therefore, synthetic polyploidisation has been utilised for breeding for many years. Recently, in vitro polyploidisation techniques have been developed for Salix viminalis (Wojciechowicz 2009), Humulus lupulus (TrojakGoluch and Skomra 2013), Miscanthus (Głowacka et al. 2010), tulip (Podwyszyńska 2011), Centella asiatica (Kaensaksiri et al. 2011), Pyrus communis (Sun et al. 2011), and Gerbera jamesonii (Gantait et al. 2011).

Tetraploids ( $2 n=4 \mathrm{x}=44)$ of daylily have taken a leading position among the daylily cultivars due to desirable traits such as vigorous growth and flowers with more intense colour (Gatlin and Brennan 2002; Gulia et al. 2009). Daylily tetraploids also have larger and thicker leaves containing more substance, and flower scapes are stronger and studier. All of the daylily tetraploid plants have been obtained by induction with colchicine (Arisumi 1972; Chen and Goeden-Kallemeyn 1979). No naturally occurring 
tetraploid daylilies have ever been reported (Saito et al. 2003; Gulia et al. 2009; Zhang et al. 2013). Instead, several taxa with the Hemerocallis species complex are naturally occurring triploids $(2 \mathrm{n}=3 \mathrm{x}=33)$ (Gulia et al. 2009). Arisumi (1970) reported that they probably originated from the unreduced egg cell since he estimated that the frequency of unreduced egg cell was 1 in 15,000 and he did not find a single unreduced pollen grain. Moreover, Zhang et al. (2013) showed that out of 29 wild Chinese evaluated genotypes, $45 \%$ were triploids and $55 \%$ were diploids $(2 \mathrm{n}=2 \mathrm{x}=22)$. Since no tetraploid was identified, the authors suggested, that all these natural triploids derived probably from unreduced gametes.

In our previous studies, we developed efficient in vitro methods of tetraploid induction for daylily (Hemerocallis $\mathrm{x}$ hybrida) using herbicidal antimitotic agents such as oryzalin, APM, and trifluralin as alternatives to colchicine (Podwyszyńska et al. 2010). Thus, the efficiency of the in vitro tetraploid induction with these antimitotic agents reached approximately $20 \%$. Several mixoploids were also obtained $(9.4 \%$ of the all regenerants) but they were not evaluated in this study. The preliminary observations of the newly obtained allotetraploids and unconverted diploids were that all regenerated from the same plant material treated with antimitotic agents and revealed marked phenotypic differences between diploids and tetraploids as well as variation within either the group of diploids or the group of tetraploids.

The purposes of the present research were to evaluate phenotypic and genome size changes in allotetraploids of daylily in relation to their diploid counterparts and to assess variation within the tetraploids and diploids derived from genetically homogenous plant material treated with antimitotic agents.

\section{Materials and methods}

Plant material

Tetraploids and unconverted diploids of Hemerocallis x hybrida 'Berlin Multi' and 'Blink of an Eye' obtained in the earlier studies from in vitro polyploidisation performed in 2009 (Podwyszyńska et al. 2010) were used for phenotype and genome size evaluation. Both tetraploid and unconverted diploid plants were derived from the in vitro shoot cultures treated with antimitotic agents $\left(\mathrm{mg} \mathrm{L}^{-1}\right)$ : colchicine $(500)$, oryzalin (5 and 15), APM (5 and 10), and trifluralin (50 and 100). The exposure time and concentrations of antimitotic agents were chosen based on our preliminary experiment and the reports of other authors who found such treatments as optimal for in vitro polyploidisation of Actinidia deliciosa, hybrids of Rhododendron, Micsanthus sinensis and Allium cepa (Chalak and Legave 1996; Väinölä 2000; Petersen et al. 2003; Jakše et al. 2003). The antimitotics were added to a regeneration medium containing Murashige and Skoog (1962) mineral and organic compositions and supplemented with cytokinins (kinetin, isopentenyladenine and benzyladenibe, each at the concentration of $1 \mathrm{mg} \mathrm{L}^{-1}$ ) combined with $0.03 \mathrm{mg} \mathrm{L}^{-1} \mathrm{TDZ}$ (Gabryszewska and Wojtania 2005). The shoot clumps were exposed to these compounds for 2-7 days and then transferred to the same medium but without antimitotics. The explants were sub-cultured four times at sixweek intervals on regeneration medium, but the concentration of cytokinins was gradually reduced. In the last regeneration subculture, the concentration of each cytokinin was reduced to $0.5 \mathrm{mg} \mathrm{L}^{-1}$ and TDZ was excluded. Then, the regenerated shoots were rooted in vitro and planted in a greenhouse. Tetraploids were detected using flow cytometry (Podwyszyńska et al. 2010).

All of the plants used for this study after transplanting from in vitro culture were grown in a greenhouse during the first year. During the second and the third seasons, the plants were grown outdoors from early May to mid-October and during the winter were kept at $5-10{ }^{\circ} \mathrm{C}$ in the greenhouse from early November to the end of January. During the rest of greenhouse growing, the temperature was maintained at $20-25{ }^{\circ} \mathrm{C}$. Plants were cultured in containers filled with growing substrate TS 1 (Kronen-Klasmann, Gryfice, Poland). During vegetation, plants were fertilised with complete fertiliser and watered as needed. The plants were sprayed against aphids and mites during the growth in greenhouse (March-April) according to the recommendation of the advisory service in the area. Numbers of diploid and tetraploid plants derived from the particular polyploidisation treatments used in our study are given in Table 1 . 
Table 1 Number of the observed plants and their origin (i.e., the previous treatment with antimitotic agents of the in vitro shoot cultures from which the plants originated)

\begin{tabular}{|c|c|c|c|c|c|c|}
\hline \multicolumn{3}{|c|}{ Polyploidisation treatment } & \multicolumn{2}{|c|}{$\begin{array}{l}\text { 'Berlin } \\
\text { Multi' }\end{array}$} & \multicolumn{2}{|c|}{$\begin{array}{l}\text { 'Blink } \\
\text { of an } \\
\text { Eye' }\end{array}$} \\
\hline $\begin{array}{l}\text { Antimitotic } \\
\text { agent }\end{array}$ & $\begin{array}{l}\text { Concentation } \\
\left(\mathrm{mg} \mathrm{L}^{-1}\right)\end{array}$ & $\begin{array}{l}\text { Time of } \\
\text { treatment } \\
\text { (days) }\end{array}$ & $2 \mathrm{x}$ & $4 \mathrm{x}$ & $2 \mathrm{x}$ & $4 x$ \\
\hline \multirow[t]{2}{*}{ Colchicine } & 500 & 2 & 0 & 0 & 0 & 0 \\
\hline & 500 & 7 & 0 & 0 & 0 & 0 \\
\hline \multirow[t]{4}{*}{ Oryzalin } & 5 & 2 & 1 & 0 & 4 & 3 \\
\hline & 5 & 7 & 0 & 0 & 0 & 0 \\
\hline & 15 & 2 & 0 & 0 & 0 & 1 \\
\hline & 15 & 7 & 0 & 0 & 0 & 0 \\
\hline \multirow[t]{4}{*}{ APM } & 5 & 2 & 0 & 0 & 3 & 3 \\
\hline & 5 & 7 & 6 & 5 & 1 & 1 \\
\hline & 10 & 2 & 0 & 0 & 13 & 5 \\
\hline & 10 & 7 & 1 & 1 & 8 & 2 \\
\hline \multirow[t]{4}{*}{ Trifluralin } & 50 & 2 & 0 & 0 & 3 & 3 \\
\hline & 50 & 7 & 2 & 1 & 6 & 3 \\
\hline & 100 & 2 & 0 & 0 & 4 & 1 \\
\hline & 100 & 7 & 0 & 1 & 0 & 1 \\
\hline \multicolumn{3}{|c|}{ Total number of plants observed } & 10 & 8 & 42 & 23 \\
\hline \multicolumn{3}{|c|}{ Number of flowering plants } & 9 & 6 & 25 & 9 \\
\hline
\end{tabular}

Phenotype evaluation

Plants were evaluated for leaf size: length of the longest leaf and width of the fourth leaf at its widest part. At flowering, polyploids were estimated as percentage of flowering plants, first flower opening time (FFO), inflorescence stem length and diameter, bud number per scape, and flower diameter of the first flower in an inflorescence. Mean FFO was calculated as total number of days that passed from a date of the first plant flowering to a flowering date of all other plants divided by the number of plants observed. Measurements concerning the leaf phenotype (length, width) were performed for all of the plants observed (i.e., 10 diploid and eight tetraploid plants of 'Berlin Multi' and 42 diploid and 23 tetraploid plants 'Blink of an Eye'. Flower parameters were evaluated in all of the flowering plants (i.e., nine diploids and six tetraploids of 'Berlin Multi' and 25 diploids and nine tetraploids of 'Blink of an Eye' (Table 1). Differences between parental donor plants and polyploids in the flower structures, size, and colour (petals, stamens, and pistils) were noted.

\section{Chlorophyll concentration index (CCI)}

The relative chlorophyll content of leaves by measuring CCI as a ratio of optical transmission at $931 \mathrm{~nm}$ divided by transmission at $653 \mathrm{~nm}$ was performed using a Chlorophyll Content Meter CCM-200 plus (Opti-Science, Hudson, USA). Measurements were made on the middle part of the fourth leaf for all of the plants observed (flowering and not flowering).

\section{Genome size (nuclear DNA content)}

Samples were taken from the middle part of the second, third, and fourth youngest leaves. Leaf tissue $\left(0.5-1 \mathrm{~cm}^{2}\right)$ was chopped together with a piece $\left(1 \mathrm{~cm}^{2}\right)$ of plant internal standard in a Petri dish in $0.5 \mathrm{~mL}$ nuclei isolation Partec buffer to which propidium iodide $(50 \mu \mathrm{g} / \mathrm{mL})$ and RNasa $(50 \mu \mathrm{g} / \mathrm{mL})$ were added (Śliwińska 2008). As an internal standard, the young leaves of Zea mays CE-777 (2C $=5.43 \mathrm{pg}$ DNA) (Institute of Experimental Botany, Olomouc, Czech Republic) were used (Lysák and Doležel 1998). After adding $1.5 \mathrm{~mL}$ of the isolation buffer, the samples were filtered through a $30-\mu \mathrm{m}$ filter and incubated for $15 \mathrm{~min}$. The fluorescence of the nuclei was measured using CyFlow Ploidy Analyser with CyView software (CyFlow PA, Partec, Germany) with an Nd-YAG green laser at $532 \mathrm{~nm}$. Data were analysed by means of CyView software (Partec). The 2C DNA content of a sample was calculated as the sample peak mean divided by the standard plant peak and multiplied by the amount of DNA of the standard plant. Samples with at least 5,000 nuclei were measured for three leaves of each plant with two runs from each nuclei isolation extract. Nuclear DNA content was evaluated for all of the diploid and tetraploid plants (10 and 8, respectively) of 'Berlin Multi' and for 15 diploid and all of the tetraploid plants (23) of 'Blink of an Eye'.

Stomata length

Sampling method was optimised based on our earlier study (Podwyszyńska et al. 2011). Thus, the samples of abaxial epidermis isolated from the third and fourth youngest leaves, $10-\mathrm{cm}$ distant from their tips were mounted on slides for microscopic observations and 
stained with toluidine blue according to the procedure of Dyki and Habdas (1996). The stomata measurements were determined for each of the two leaves of each plant using a Nikon Eclipse 80i microscope with the program NIS-Elements BR 2.30, at 400 times magnification. Samples were collected from seven diploid and seven tetraploid plants of the cultivar 'Blink of an Eye' (three diploids most similar to the diploid standard and four diploid variants as well as three tetraploids of the reproducible phenotype and four tetraploid variants).

\section{Pollen grain length and viability}

A mixed sample of pollen each from 2 to 6 anthers of each plant analysed were stained with acetocarmine. The pollen germination was tested on the microscope slides with different sucrose solutions (from 2 to $10 \%$ ) after 2, 4, and $6 \mathrm{~h}$ of incubation at room temperature (Niles and Quesenberry 1992). Tests of pollen germination (in vitro) in sucrose solutions had not been successful; therefore, pollen germination was evaluated on the stigma pistil in the process of selfpollinating plants. The stigma pistils removed from two or three diploid and tetraploid plants of both cultivars were isolated and stained with aniline blue after being macerated in $1 \% \mathrm{NaOH}$ at $60{ }^{\circ} \mathrm{C}$ for observation of viable, germinated pollen grains (Dyki 1978). Measurement of pollen grain length was performed using a microscope as described for stomata measurements (see above). The pollen viability was checked with a fluorescence microscope (Nikon Eclipse 50i) with the program NIS-Elements BR 2.30. Pollen was collected from 11 randomly selected diploid and six tetraploid plants of both cultivars.

\section{Statistical analysis}

Data concerning leaf and flower traits and CCI were subjected to an analysis of variance (ANOVA). Data of nuclear DNA content, stomata, and pollen sizes were analysed with ANOVA-nested design. The means were compared by Tukey's test at $p=0.05$.

\section{Results}

During the first season in the greenhouse, tetraploids grew very slowly and had much smaller leaves (narrower and shorter), but they were thicker with an uneven surface (not smooth) compared to the unconverted diploids (Fig. 1). All of the regenerated diploids and tetraploids derived from the plant material treated with colchicine died during the first year of growing. No evident differences were identified in leaf phenotype within the group of diploids or the group of tetraploids regardless of antimitotic treatment (oryzalin, APM, or trifluralin). In the second season, the growth of tetraploids was much more vigorous than that of diploids. However, none of tetraploids flowered, and only four unconverted diploid plants formed flowers. The leaf width in 'Blink of an Eye' was significantly higher for tetraploids compared to diploids, 19 and $17 \mathrm{~mm}$, respectively. In tetraploids of both cultivars, the leaves were more green.

In the third growing season (two and-a-half years of growing plants ex vitro), flowering was more abundant. However, the tetraploids flowered in lower percentages than diploids, 75 and $90 \%$, respectively, in 'Berlin Multi' and 39.1 and $59.5 \%$, respectively, in 'Blink of Eye' (Table 2). Compared to diploids, in tetraploids average FFO was delayed by 8 days in 'Blink of an Eye' and by 30 days in 'Berlin Multi'. Flower diameters of tetraploids were significantly larger in both cultivars: by $2 \mathrm{~cm}$ in 'Berlin Multi' and

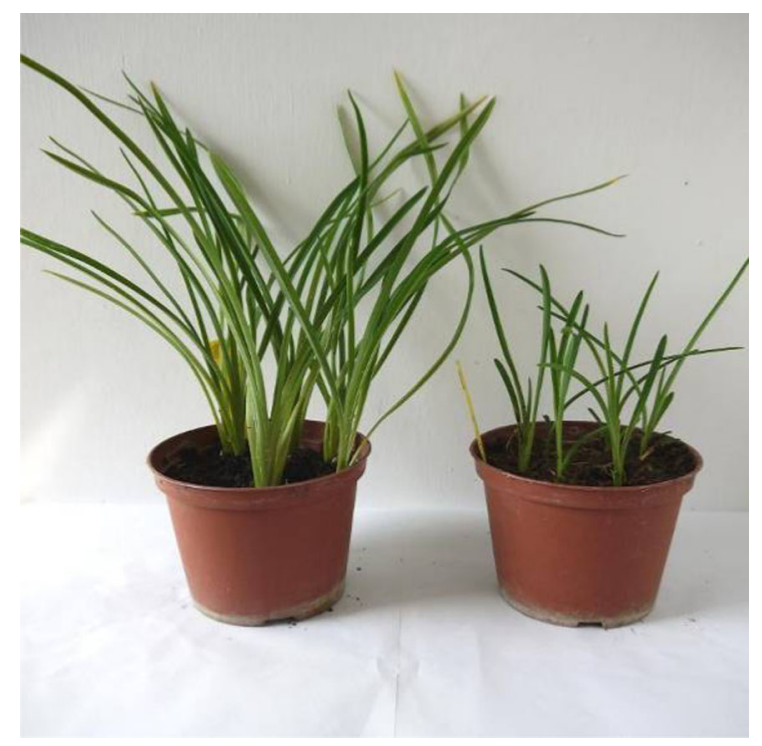

Fig. 1 Phenotypes of juvenile 'Blink of an Eye' daylily plants regenerated in vitro from shoot cultures treated with APM and then grown in a greenhouse for 1 year; from the left unconverted diploid plant and poorly growing tetraploid 


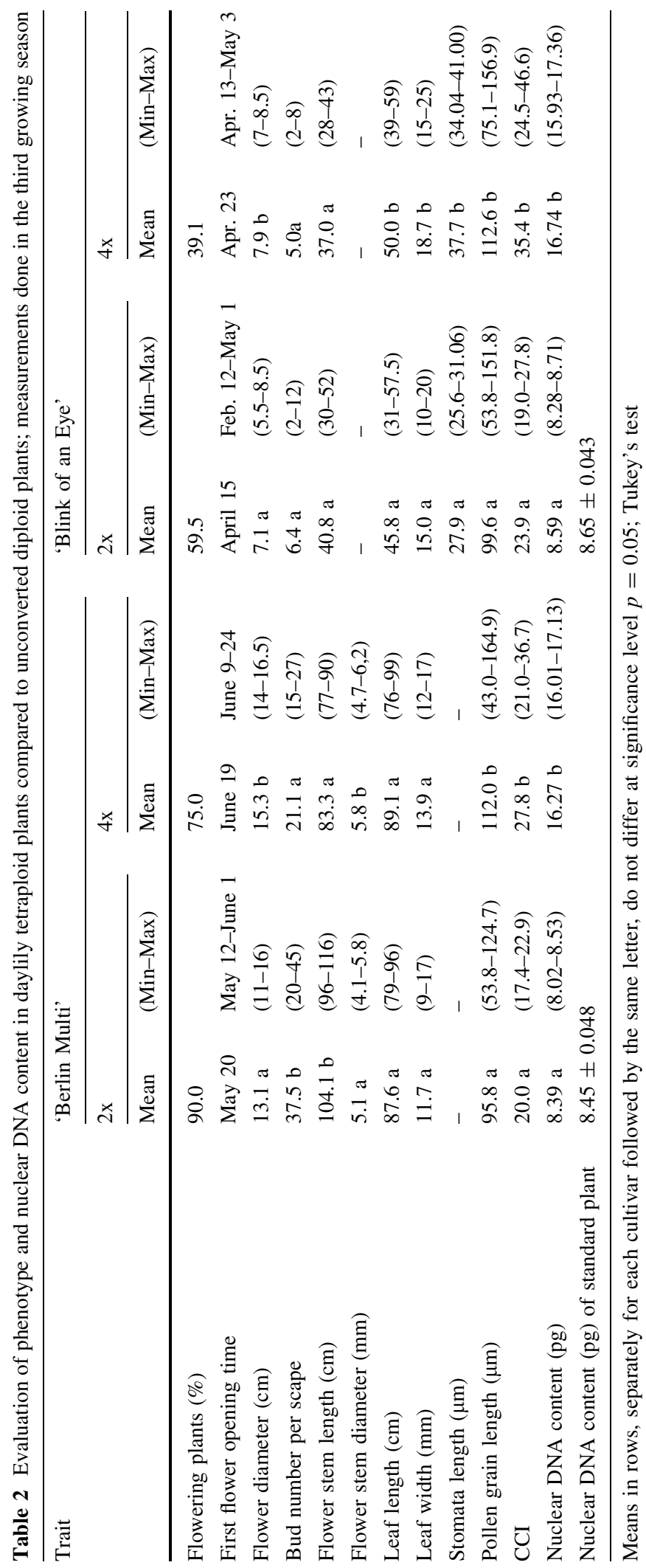




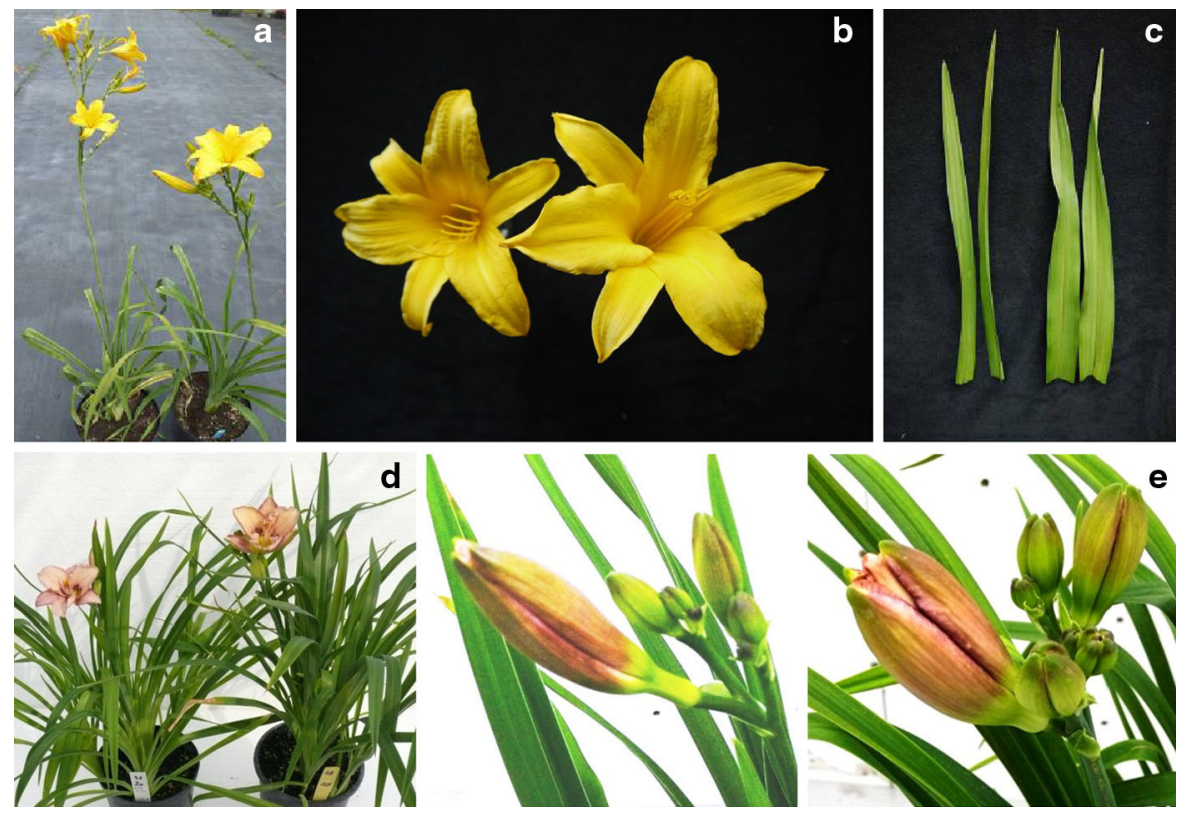

Fig. 2 Phenotype of flowering daylily plants (flowers, leaves, or flower buds) during the third growing season; on each photograph from the left unconverted diploid and tetraploid plant: a and b 'Berlin Multi'; c, d, and e 'Blink of an Eye'
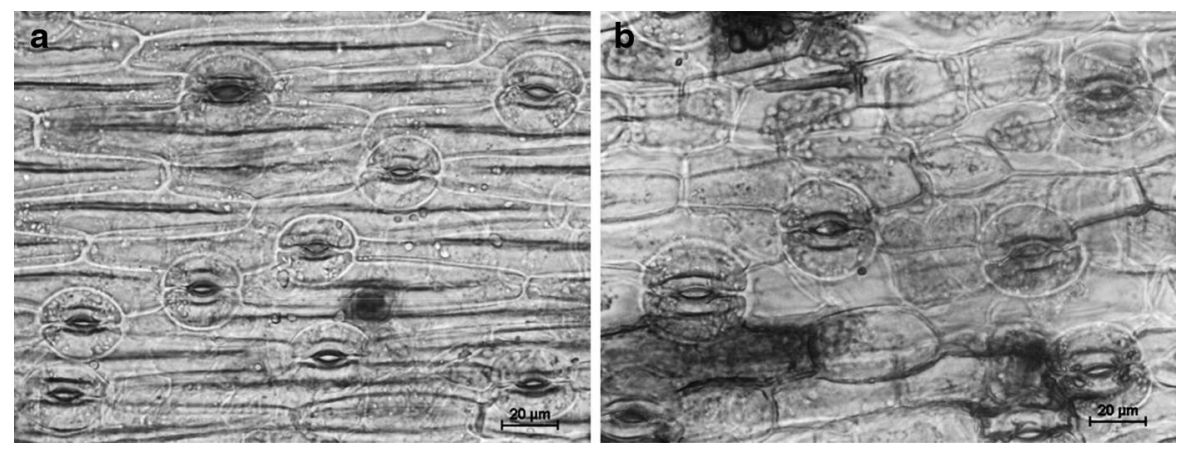

Fig. 3 Stomata of daylily plants stained with toluidine blue: a unconverted diploid and b tetraploid; bars represent $20 \mu \mathrm{m}$

$0.8 \mathrm{~cm}$ in 'Blink of an Eye' (Table 2; Fig. 2a, b, d). Bud number per scape was, however, significantly lower in tetraploids than in diploids of both cultivars by approximately $40 \%$ in 'Berlin Multi' and $20 \%$ in 'Blink of an Eye'. In general, the tetraploids had more robust buds and compact scapes (Fig. 2e). The stem diameter, measured only in 'Berlin Multi', was higher in tetraploids. In this cultivar, inflorescence stems were markedly shorter by $20 \%$ in tetraploids (Table 2; Fig. 2a). In tetraploids of both cultivars, leaves were larger than in diploids, but significant differences were found only in 'Blink of an Eye', where tetraploid leaves were longer by $5 \mathrm{~cm}$ and wider by $3.7 \mathrm{~mm}$ (Table 2; Fig. 2c). Chlorophyll concentration index was markedly higher by approximately $40 \%$ in tetraploids of both cultivars compared to diploids. Microscopic observations performed in 'Blink of an Eye' showed that stomata of tetraploids were longer by $35 \%$ than those of diploids (Table 2; Figs. 3, 4).

In the studied genotypes, the majority of pollen grains are characterised by a spindle-like shape and similar surface structure (Fig. 5). Changes in the shape of pollen grain characteristics were usually associated with an alteration in their size (Fig. 6). Variation in length of pollen grains within the single plant was 
Fig. 4 Stomata length (mean \pm SD and Min-Max) of 'Blink of an Eye' daylily plants $(\mathrm{n}=20)$ : $(d 1-d 3)$ diploids most similar to diploid standard; $(d 38, d 40$, $d 58$, and $d 59)$ diploid variants; $(t 1-t 3)$ tetraploids of the reproducible phenotype; $(t 18, t 26, t 77$, and $t 85)$ tetraploid variants

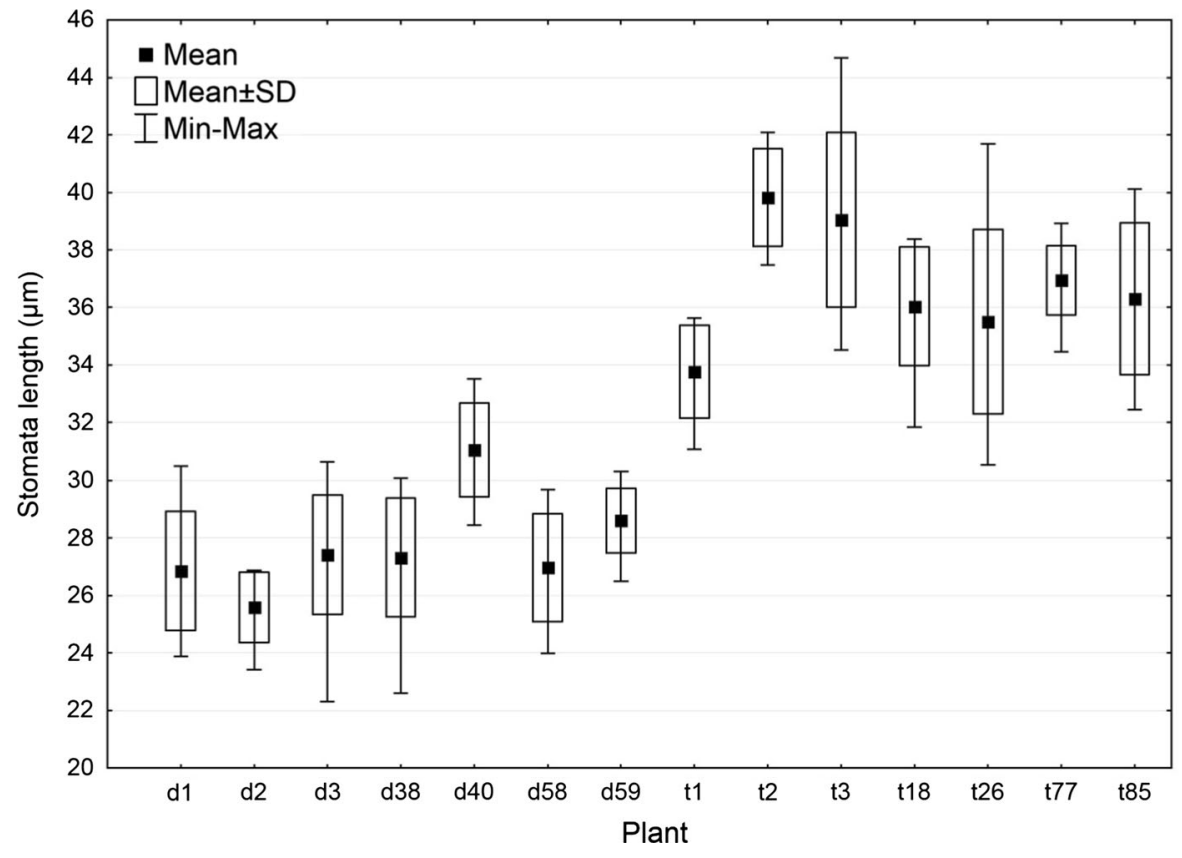

observed in both diploid and tetraploid forms, but in general the higher standard deviations (SDs) were noted for tetraploids (Fig. 6). The pollen grains showed differences in staining with acetocarmine, which may indicate different viability (Fig. 5a-d). Tests of pollen germination (in vitro) in sucrose solutions have not been successful; therefore, pollen germination was evaluated on the stigma pistil in the process of self-pollinating plants (Fig. 5e, f). Many germinating pollen grains and long pollen tubes were observed in the diploid and tetraploid plants, but there were more in diploids (data not presented).

Flow cytometry analysis revealed the obvious difference of the nearly two-fold higher nuclear DNA content in tetraploids compared to diploids (Tables 2, 3, 4; Fig. 7a, b). Since the nuclear DNA contents in standard diploid plants of 'Berlin Multi' and 'Blink of an Eye' were 8.45 and $8.65 \mathrm{pg}$, respectively, the theoretically expected DNA content should be 16.9 and $17.3 \mathrm{pg}$ for tetraploids of those cultivars, respectively. But the nuclear DNA contents in the newly obtained tetraploids were usually lower with averages of 16.27 and $16.74 \mathrm{pg}$ in 'Berlin Multi' and 'Blink of an Eye', respectively. In both cultivars, variation was found in the nuclear DNA content within either unconverted diploids or tetraploids, which ranged from 8.02 to $8.53 \mathrm{pg}$ in diploids and
16.01-17.13 pg in tetraploids of 'Berlin Multi' and 8.28-8.71 pg in diploids and $15.93-17.36 \mathrm{pg}$ tetraploids of 'Blink of an Eye'.

We also detected variation in flower morphology of 'Blink of an Eye' within either group of unconverted diploid or tetraploid plants obtained from genetically homogenous plant material treated with different antimitotic agents (Tables 3, 4; Figs. 8, 9). Differences were found in flower morphology (colour tone and flower shape) and stamen malformation (lack of anthers). The variation within diploids was rather low. Four diploid variants were selected (Table 3; Fig. 8). Two of these variants ( $\mathrm{d} 38$ and $\mathrm{d} 40$ ) were derived from plant material treated with APM at $10 \mathrm{mg} \mathrm{L}^{-1}$ for 7 days and other variants (d58 and d59) were derived from material treated with trifluralin at $50 \mathrm{mg} \mathrm{L}^{-1}$ for 7 days. The variants, $d 38$ with slightly changed flower shape, d40 having 8 petals, and d59 with brighter petals and shorter stamens, all had similar nuclear DNA contents. The variant d58 with one stamen fused with a petal had significantly lower DNA content compared to all other diploid variants. More evident variation was found in tetraploids. In general, all of the tetraploid plants were characterised with more compact flowers (i.e., petals were less open but the flowers of selected variants $\mathrm{t} 77$ and $\mathrm{t} 85$ petals were even less open, creating a trumpet-shaped flower (Table 4; 

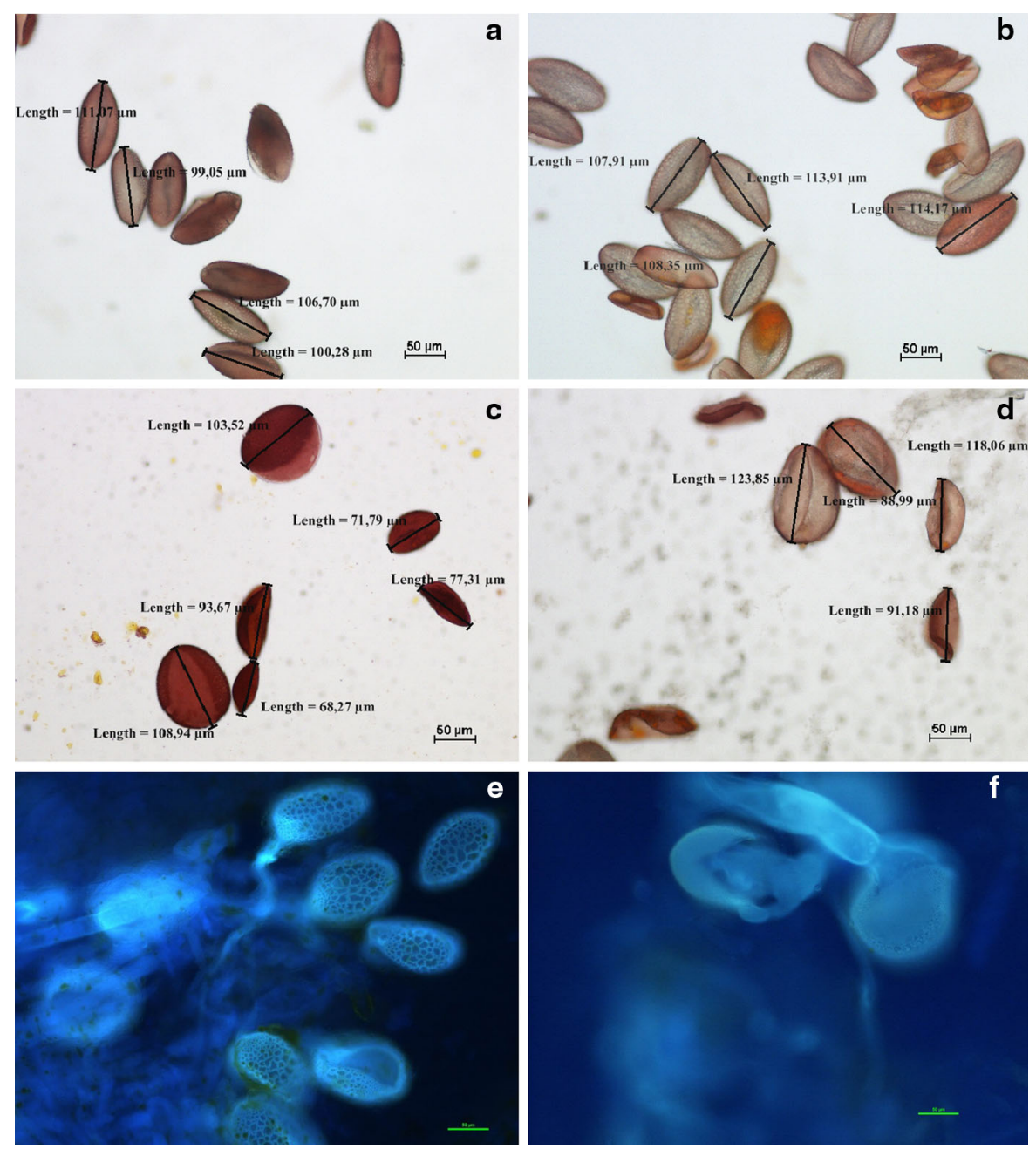

Fig. 5 Pollen grains of 'Blink of an Eye' daylily plants (a-d) acetocarmine stained and (e and $\mathbf{f}$ ) aniline blue stained and analysed with fluorescence microscopy. Regular viable pollen:

Fig. 9). The most changed plant (t26) had flowers with green throats, three stamens fused with petals, and three remaining stamens with no anthers. The tetraploid variants derived from plant material which was treated with APM at $10 \mathrm{mg} \mathrm{L}^{-1}$ for 7 days or oryzalin at $5 \mathrm{mg} \mathrm{L}^{-1}$ for 2 days.

\section{Discussion}

The mechanisms by which polyploidy affects phenotype and contributes to increased variation in allopolyploids (genetic and epigenetic changes, dosage-regulated gene expression, and homologous recombination) have been

a diploid and b tetraploids. Irregular low-viability pollen: $\mathbf{c}$ diploid and $\mathbf{d}$ tetraploids. Pollen grains germinating on stigma: e diploid and $\mathbf{f}$ tetraploids. Bars represent $50 \mu \mathrm{m}$

recently widely reviewed (Osborn et al. 2003; Chen 2007; Rogalska et al. 2007; Madlung and Wendel 2013). Less attention has been paid to autotetraploidy, which also involves genetic and epigenetic changes (Ramanna and Jacobsen 2003; Stupar et al. 2007; Anssour et al. 2009; Parisod et al. 2010). Polyploidisation has long been considered a prominent factor in the evolution of plant species. Many of the important crop plants are allopolyploids, including strawberry (allooctoploid) (Marta et al. 2004), wheat (allohexaploid) (Rogalska et al. 2007), oilseed rape (allotetraploid) (Snowdon 2007), banana (allotriploid) (Simmonds 1995), and Darwin group tulips (allotriploids) (Marasek and Okazaki 2008). There is the hypothesis that every plant species underwent through 
Fig. 6 Pollen grain length (mean \pm SD and Min-Max) of 'Berlin Multi' and 'Blink of an Eye' daylily plants $(\mathrm{n}=20):(d 1-d 11)$ diploids; $(t 1-t 6)$ tetraploids
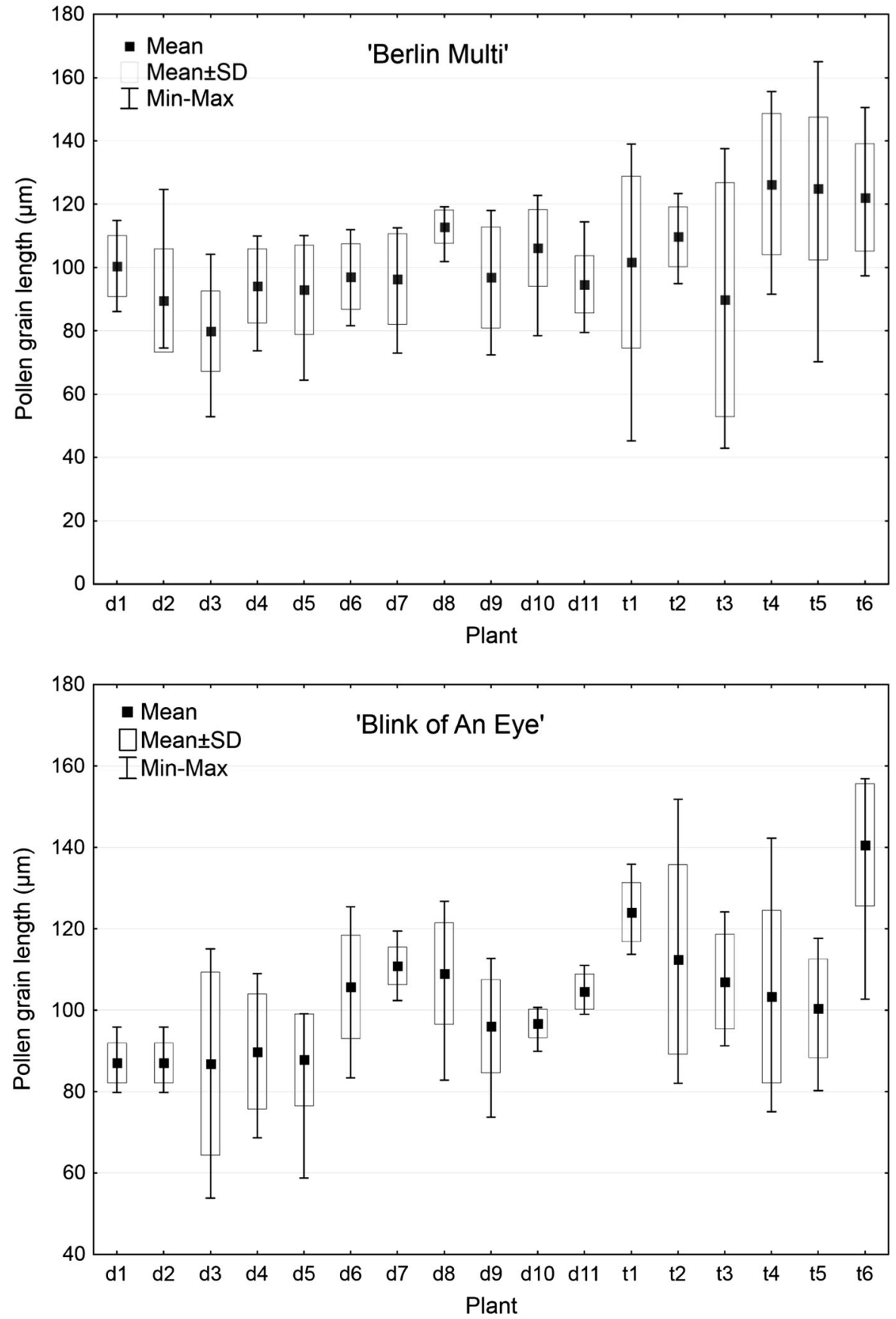

cycles of polyploidisation during their evolution (Osborn et al. 2003). Polyploid breeding is just a simulation of a polyploidisation occurring in nature. The phenomenon of structural and functional genome alteration caused by polyploidisation is recognised as a source of genetic diversity. Anssour et al. (2009) has demonstrated that both types of polyploidization (allo- and auto-) are associated with dynamic and rapid structural and functional genome alterations, but the scope of changes in autopolyploids has been concluded to be less.

In our study, the polyploidisation of daylily caused distinct alteration in phenotype. Compared to diploids, the newly obtained allotetraploids had larger stomata, pollen grains, leaves, and flowers. Similar 
Table 3 Evaluation of variation within daylily unconverted diploids 'Blink of an Eye', observations done in the third growing season

\begin{tabular}{llll}
\hline $\begin{array}{l}\text { Selected diploid } \\
\text { variants }\end{array}$ & $\begin{array}{l}\text { Antimitotic agent, concentration } \\
\left(\mathrm{mg} \mathrm{L}^{-1}\right), \text { treatment time (days, d) }\end{array}$ & $\begin{array}{l}\text { Flower phenotype, changes } \\
\text { compared to diploid standard }\end{array}$ & $\begin{array}{l}\text { Nuclear DNA } \\
\text { content } \pm \text { SD }(\mathrm{pg})\end{array}$ \\
\hline Standard & - & Pink-violet petals, violet throat, six petals & $8.65 \pm 0.035$ \\
d38 & AMP, 10, 7d & Slightly changed flower shape & $8.70 \pm 0.050$ \\
d40 & AMP, 10, 7d & Eight petals & $8.66 \pm 0.064$ \\
d58 & Trifluralin, 50, 7d & One stamen fused with petal & $8.28 \pm 0.043$ \\
d59 & Trifluralin, 50, 7d & Brighter petals, shorter stamens & $8.56 \pm 0.025$ \\
\hline
\end{tabular}

Data of the nuclear DNA content represent mean \pm SD of three samples each with two replications

Table 4 Evaluation of variation within daylily tetraploid plants 'Blink of an Eye', observations done in the third growing season

\begin{tabular}{|c|c|c|c|}
\hline $\begin{array}{l}\text { Selected tetraploid } \\
\text { variants }\end{array}$ & $\begin{array}{l}\text { Antimitotic agent, concentration } \\
\left(\mathrm{mg} \mathrm{L}^{-1}\right), \text { treatment time (days, d) }\end{array}$ & $\begin{array}{l}\text { Flower phenotype, changes } \\
\text { compared to diploid standard }\end{array}$ & $\begin{array}{l}\text { Nuclear DNA } \\
\text { content } \pm \text { SD (pg) }\end{array}$ \\
\hline $\mathrm{t} 18$ & AMP, $10,2 d$ & $\begin{array}{l}\text { Most similar to diploid standard, properly } \\
\text { formed flower organs }\end{array}$ & $16.78 \pm 0.049$ \\
\hline $\mathrm{t} 26$ & AMP, $10,2 d$ & $\begin{array}{l}\text { Green throat, three stamens fused with } \\
\text { petals, anthers malformed }\end{array}$ & $16.29 \pm 0.070$ \\
\hline $\mathrm{t} 77$ & Oryzalin, 5, 2d & Trumpet-shaped flower & $16.60 \pm 0.065$ \\
\hline $\mathrm{t} 85$ & Oryzalin, 5, 2d & Trumpet-shaped flower, brighter petals & $16.67 \pm 0.040$ \\
\hline
\end{tabular}

Data of the nuclear DNA content represent mean \pm SD of three samples each with two replications

observations concerning enhancement of cells, stomata, and organs were noted in newly obtained autotetraploids of Zantedeschia (Cohen and Yao 1996), Chaenomeles japonica (Stanys et al. 2006), potato (Stupar et al. 2007), Nicotiana sp. (Anssour et al. 2009), and Gerbera jamesonii (Gantait et al. 2011). Zhang et al. (2013) reported that naturally occurring triploid genotypes and tetraploid cultivars of Hemerocallis had significantly thicker flower stems and wider leaves similarly as in our tetraploid plants. We also found that the chlorophyll content was higher in daylily tetraploids compared to diploids. This increase in chlorophyll content has been often observed e.g., in neotetraploids of Vicia villosa (Elradi and Unal 2010), mango (González-Rodríguez and Grajal-Martín 2013), and watermelon (Jaskani et al. 2005). In general, tetraploidisation resulted in positive trends in enhancement of cells, stomata, organs, plant vigor, and/or biomass. However, depending on genotype and characteristics, tetraploidisation has been also reported to be associated with a negative correlation. In potato, cell size and organ thickness were positively correlated with the ploidy level, but the tetraploid plants were generally less vigorous compared to diploids (Stupar et al. 2007). In Centella asiatica, the cytological features and some organs were larger. However, traits such as leaf size, fresh and dry weight, and bioactive substance (triterpenes) content were similar in diploid and tetraploid plants, and the numbers of stolons and leaves per plant were lower in tetraploids (Kaensaksiri et al. 2011). Our observations correspond well with these reports. Although, in our daylily tetraploids the stomata, leaves, and flowers were larger, the bud number per scape was lower in both cultivars, and the stem length, depending on cultivar, was similar or lower compared to diploids. Negative correlation associated with tetraploidisation was also noted in Rosa rugosa for the number of flowers per inflorescence (Allum et al. 2007) as well as the number of flowers per plant and the stem length in Vicia villosa (Elradi and Unal 2010). Reduction in plant height was noted for some fruit plants such as cherry rootstock (Webster 1996) and citrus hybrid trees (Jaskani and Khan 2000). Moreover, in our study, the flowering of tetraploids was delayed compared to diploid counterparts. Additionally, the tetraploids flowered in lower percentages. Similar delays in flowering time of a few days were 


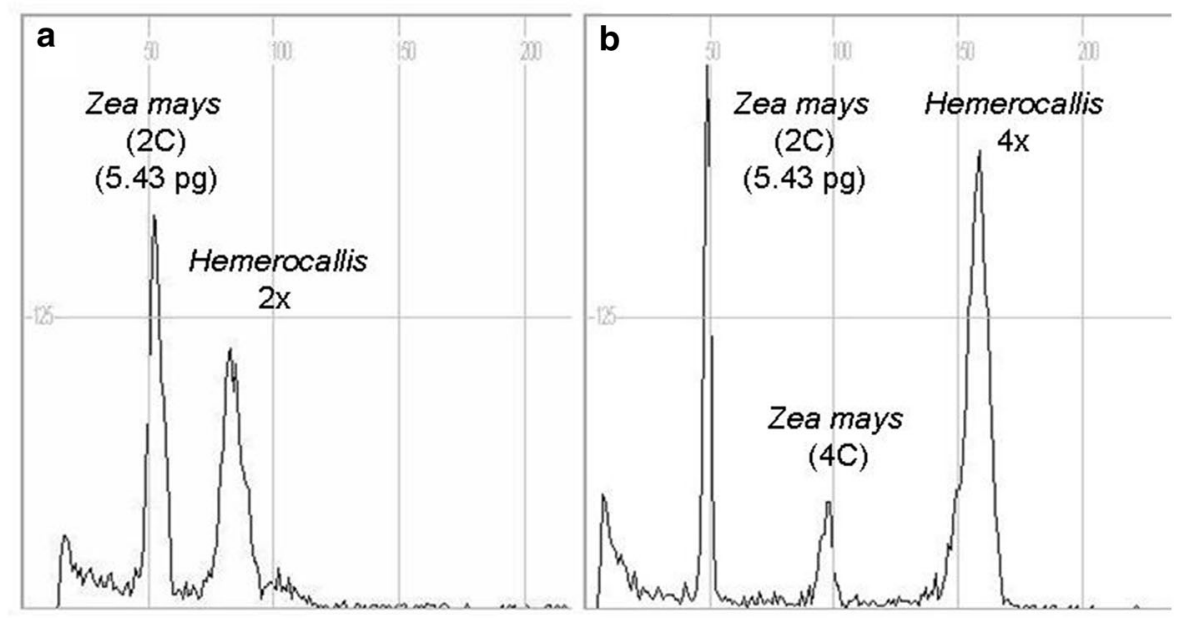

Fig. 7 Histograms of nuclear DNA content of nuclei isolated from young leaves of daylily plants: a diploid and b tetraploids. Zea mays CE-777 (2C $=5.43$ pg DNA) was used as an internal standard

Fig. 8 Flowers of diploid variants $(d 38, d 40, d 58$, and d59) of 'Blink of an Eye' daylilies and selected within the plants regenerated from the in vitro shoot cultures treated with antimitotic agents; St standard plant
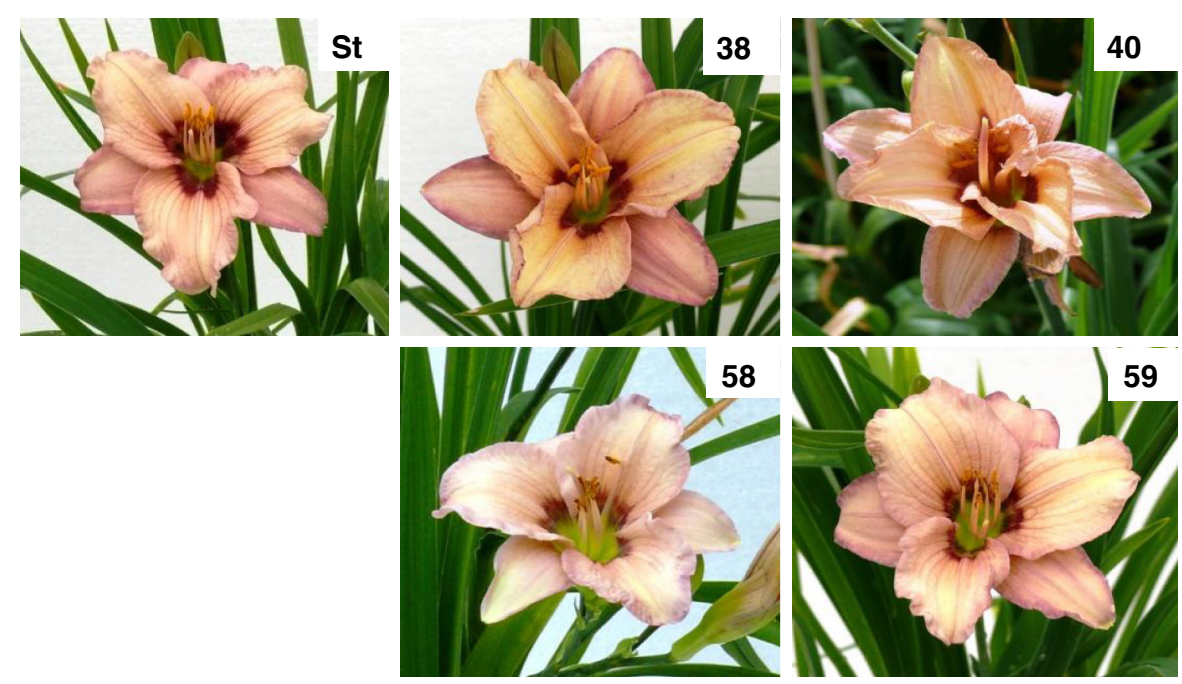

noted in autotetraploids of Zizyphus jujube (Gu et al. 2005) and Gerbera jamesonii (Gantait et al. 2011) and delays of 2 and 3 weeks in Citrullus lanatus (Jaskani et al. 2005) and Vicia villosa (Elradi and Unal 2010), respectively.

Our observations showed that initial growth of tetraploids was very slow, but during the next season tetraploids were significantly larger than diploids. Joshi and Verma (2004) also reported that newly obtained polyploid plants were slower in growth initially but later surpassed in growth parameters their diploid counterparts. In turn, a decrease in the in vitro Pyrus communis shoot and root organogenic potential was found by Sun et al. (2011). Such decrease of in vitro organogenic ability of polyploids was attributed to the difficulty of normal completion of mitosis or the tendency to produce aneuploid cells during mitosis. As reported by Comai (2005), the aneuploid cells grow slowly and are overgrown by the preferential proliferation of surrounding euploid cells. Stebbins (1984) reported that the diminished growth rate after polyploidisation resulted from reduced rate of cell division. Slower mitotic rhythm and more sluggish growth of polyploids have been reported since the 1940s (Levan 1943). This author suggested that since the polyploid nuclei, cells, and organs were larger, 
Fig. 9 Flowers of tetraploids variants $(t 18, t 26$, $t 40, t 77$, and $t 85$ ) of 'Blink of an Eye' daylilies selected within the plants obtained from the in vitro polyploidisation

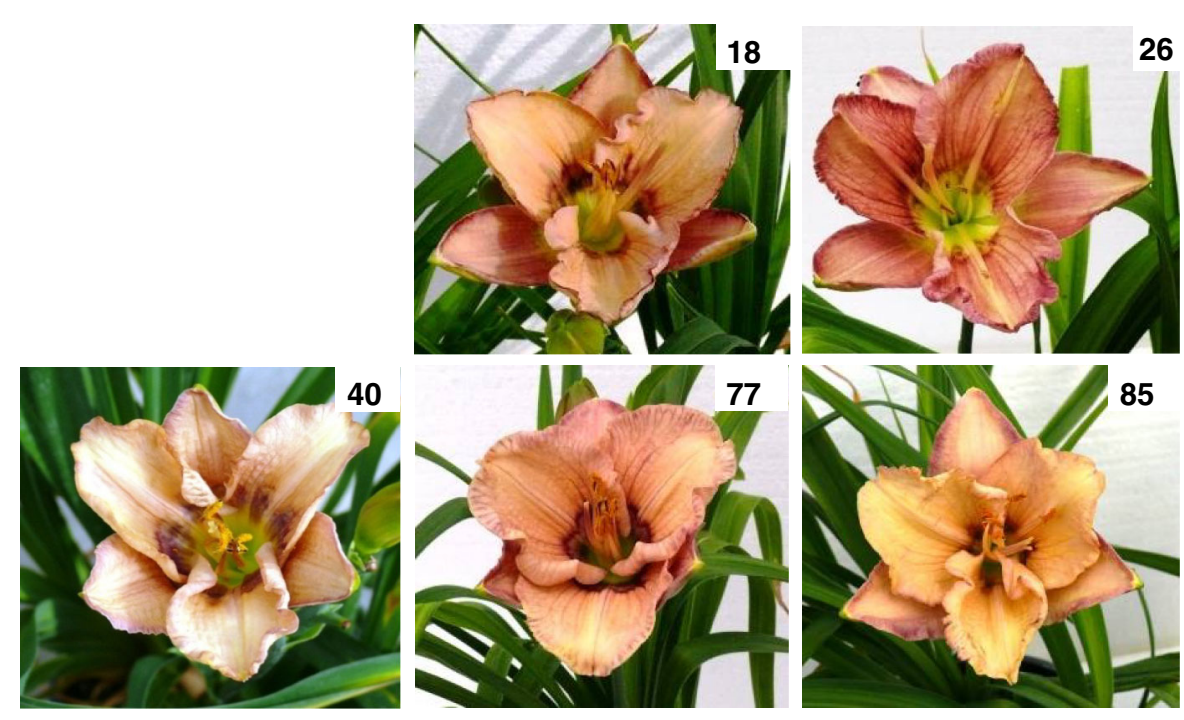

drummondi or Elymus elongates (Parisod et al. 2010).

they needed more time for building up. On the other hand, in our study, the poor growth of daylily tetraploids observed during the first season was transient. However, during the first winter in a cold greenhouse our diploid and tetraploid regenerants underwent dormancy, and in the second and third seasons, their growth was more vigorous compared to diploids. We suggest that this shift in the growth intensity of tetraploids could have a nature of epigenetic alteration resulting from the changes of DNA methylation pattern occurring during genome stabilisation after chromosome doubling. We suppose that the process of dormancy development/recovery can be one of the factors involved in genome stabilisation related to DNA methylation rate.

The process of genome functional reorganisation (i.e., alteration in gene expression) came from methylation or transposon relocation triggered by polyploidisation has intense character in allopolyploids (Osborn et al. 2003; Rogalska et al. 2007; Chen 2007). In autopolyploids, the extent of such modulation in gene expression, such as that caused by epigenetic changes, is suggested to be less (Stupar et al. 2007; Anssour et al. 2009; Parisod et al. 2010).

In our study, the nuclear DNA contents in the newly obtained daylily allotetraploids were usually lower than expected by an average of 3-4\%. In one of the tetraploids, the nuclear DNA content was reduced by nearly $8 \%$. Immediate elimination of $10-25 \%$ of total DNA was also observed in synthetic autopolyploids compared with their diploid progenitors in Phlox Authors suggested that in autopolyploids, DNA elimination and other chromosome changes (e.g., DNA translocation, asymmetrical relocation, and loss in rDNA) can be part of a mechanism leading to structural diploidisation. Parisod et al. (2010) concluded that rapid elimination of DNA sequences from autopolyploid genomes seems to occur, but the limited data available so far imply that autopolyploids experience less genome restructuring than allopolyploids.

In turn, Anssour et al. (2009) reported several lines of evidence on the structural and molecular background of genome alterations concerning the natural and synthetic allo- and autopolyploids of Nicotiana sp. Thus, both allo- and autotetraploidy induced morphological, genetic, and genomic changes in Nicotiana. In both types of polyploids, flow cytometry analysis revealed a genome size dosage effect, but in autotetraploids the genome sizes were smaller by $10 \%$ than expected (1.8 and 1.6-fold the genome sizes of their diploid counterparts). Authors suggested that it could result from an aneuploidy or DNA fragment loss. On the other hand, both in the synthetic and natural allotetraploids, the genome sizes were similar to the theoretical size (calculated sum of their diploid components). Other studies on Nicotiana polyploidization (as reviewed by Anssour et al. 2009) revealed that the genetic and genomic alterations resulted from the following reasons: gene conversion, sequence elimination, rDNA loci changes, transposon activation, tandem and dispersed sequence evolution, 
chromosomal rearrangements, chromosomal breaks, homologous synapse formation, and genome size changes (mainly reduction). In our study, the background of phenotype and genome size alteration is unknown, and further study using cytological and molecular analyses of our daylily neotetraploids and unconverted diploids could explain the reasons for these changes.

Our study showed that variation in pollen grain size was higher in tetraploids compared to diploids. The majority of the tetraploid pollen grains were larger than in diploids, but the relatively high number of small pollen grains was also observed. Although the germinating pollen grains on the stigma were observed either in diploid or tetraploid plants, the less abundant germination was noted in tetraploids, indicating lower fertility. We suppose that lower fertility occurring in our neopolyploids may be caused by multivalent formation after genome multiplication involving meiotic irregularities. Supporting data were provided by Peck and Peck (1969) who reported that the first daylily tetraploid cultivars were not as fertile as diploids due to the abnormal meiosis with multivalent formation resulted in chromosome laggers and bridges Lower fertility was also reported for neoautotetraploids of Vicia villosa (Elradi and Unal 2010) and Citrullus lanatus (Jaskani et al. 2005). This lower pollen viability of autotetraploid plants has been attributed to instability of chromosome number during abnormal meiosis (Elradi and Unal 2010). The authors observed irregularities such as, in metaphase I, univalent and tetravalent formation in some cells or single chromosome and chromosome groups located outside of the equatorial plate; and, in anaphase II, the chromosome bridges, lagging chromosomes, chromosome fragments, and different spindle orientation. Moreover, except for the regular microspore tetrads, also some triads, pentads, and even formation of more small spores (ranging from 6-9) were observed during microsporogenesis (Elradi and Unal 2010). We supposed that similar irregularities in meiosis also could have occurred in our daylily allotetraploids since the pollen grains were very irregular in size. On the other hand, Gulia et al. (2009) reported that the modern daylily tetraploids are as fertile as their diploids due to specific genes that prevent multivalent formation as reported for maize (Jackson and Casey 1982).

Additionally, in the daylily cultivar 'Blink of an Eye', we found variation in flower morphology, stomata size, and nuclear DNA content within the tetraploid plants obtained from the genetically homogenous plant material treated with various antimitotic agents, oryzalin, trifluralin, or APM. Similar phenotypic variation was noted among neotetraploids of Pyrus communis induced in vitro with colchicine (Sun et al. 2011). The variant plantlets had alterations in leaf characteristics. Sun et al. (2011) suggested that chromosome doubling not only resulted in chromosome and gene redundancy but probably also with other types of chromosomal and gene mutations such as chromosomal rearrangements, inversions, translocations, and deletions. The chromosomal alterations and other mutation types resulting from the process of polyploidisation per se were well documented (Stupar et al. 2007; Anssour et al. 2009). In our study, the variation, while less evident, also occurred in the diploids regenerated from antimitotic treated material. We suppose that these variations could be due to antimitotic agents that can induce not only chromosome doubling but also chromosomal and gene mutations.

To conclude, the marked variation observed within mitotic tetraploids, more evident than in diploid regenerants, can be caused by genome duplication, which can constitute the mutagenic factor per se. The extent and character of these changes can be related to parental genotype and/or antimitotic agent. Further research is required at the cytological and molecular level to explain the character of changes, epigenetic and/or genetic, which influenced phenotype and nuclear DNA content.

Acknowledgments This work was supported by The National Centre for Research and Development, Grant No. N R12 0063/2009.

Open Access This article is distributed under the terms of the Creative Commons Attribution License which permits any use, distribution, and reproduction in any medium, provided the original author(s) and the source are credited.

\section{References}

Allum JF, Bringloe DH, Roberts AV (2007) Chromosome doubling in a Rosa rugosa Thunb. hybrid by exposure of in vitro nodes to oryzalin: the effects of node length, oryzalin concentration, and exposure time. Plant Cell Rep 26:977-1984

Anssour S, Krugel T, Sharbel TF, Saluz HP, Bonaventure G, Baldwin IT (2009) Phenotypic, genetic, and genomic 
consequences of natural and synthetic polyploidisation of Nicotiana attenuata and Nicotiana obtusifolia. Ann Bot 103:1207-1217

Arisumi T (1970) Experiments in breeding for triploid daylilies. Daylily J 24(2):33-37

Arisumi T (1972) Stabilities of colchicine-induced tetraploid and cytochimeral daylilies. J Hered 63:15-18

Barba-Gonzalez R, Miller CT, Ramanna MS, Van Tuyl JM (2006) Nitrous oxide $\left(\mathrm{N}_{2} \mathrm{O}\right)$ induces $2 n$ gametes in sterile $\mathrm{F}_{1}$ hybrids of Oriental x Asiatic lily (Lilium) and leads to intergenomic recombination. Euphytica 148:303-309

Carvalho JFRP, Carvalho CR, Otoni WC (2005) In vitro induction of polyploidy in annatto (Bixa orellana). Plant Cell Tiss Organ Cult 80:69-75

Chalak L, Legave MJ (1996) Oryzalin combined with adventitious regeneration for an efficient chromosome doubling of trihaploid kiwifruit. Plant Cell Rep 16:97-100

Chen ZJ (2007) Genetic and epigenetic mechanisms for gene expression and phenotypic variation in plant polyploids. Annu Rev Plant Biol 58:377-406

Chen CH, Goeden-Kallemeyn YC (1979) In vitro induction of tetraploid plants from colchicine-treated diploid daylily callus. Euphytica 28:705-709

Cohen D, Yao JL (1996) In vitro chromosome doubling of nine Zantedeschia cultivars. Plant Cell Tiss Organ Cult 47:43-49

Comai L (2005) The advantages and disadvantages of being polyploid. Nat Rev Genet 6:836-846

Dewitte A, Eeckhaut T, Van Huylenbroeck J, Van Bockstaele $\mathrm{E}$ (2010) Induction of $2 n$ pollen formation in Begonia by trifluralin and $\mathrm{N}_{2} \mathrm{O}$ treatments. Euphytica 171:283-293

Dhooghe E, Denis S, Eeckhaut T, Reheul D, Van Labeke MC (2009a) In vitro induction of tetraploids in Ranunculus. Euphytica 168:33-40

Dhooghe E, Grunewald W, Leus L, Van Labeke MC (2009b) In vitro polyploidisation of Helleborus species. Euphytica 165:89-95

Dhooghe E, Van Laere K, Eeckhaut T, Leus L, Van Huylenbroeck J (2011) Mitotic chromosome doubling of plant tissues in vitro. Plant Cell Tiss Organ Cult 104:359-373

Dyki B (1978) The use of a fluorescence technique for the investigation of self sterility in breeding lines of cauliflower. Biuletyn Warzywniczy 21:267-272 (In Polish with English abstract)

Dyki B, Habdas H (1996) Metoda izolowania epidermy liści pomidora i ogórka dla mikroskopowej oceny rozwoju grzybów patogenicznych. The method of isolation of epidermis of tomato and cucumber leaves for microscopic investigation of pathogenic fungus development). Acta Agrobot 49:123-129 (in Polish with English abstract)

Elradi T, Unal M (2010) Production of colchicine-induced tetraploids in Vicia villosa Roth. Caryologia 63:292-303

Gabryszewska E, Wojtania A (2005) Metody rozmnażania liliowca (In vitro propagation methods of daylily (Hemerocallis sp.). Zeszyty Problemowe Postępów Nauk Rolniczych 504:575-583 (In Polish with English abstract)

Gantait S, Mandal N, Bhattacharyya S, Das PK (2011) Induction and identification of tetraploids using in vitro colchicine treatment of Gerbera jamesonii Bolus cv. Sciella. Plant Cell Tiss Organ Cult 106:485-493
Gatlin FL, Brennan JR (2002) Tetraploid daylilies. The new daylily handbook. American Hemerocallis Society Inc, USA, pp 251-264

Głowacka K, Jeżowski S, Kaczmarek Z (2010) Impact of colchicine application during callus induction and shoot regeneration on micropropagation and polyploidisation rates in two Miscanthus species. In Vitro Cell Dev Biol Plant 46:161-171

González-Rodríguez AM, Grajal-Martín MJ (2013) Physiological behaviour of mangos with different ploidy levels. Acta Hort 992:155-158

Gu XF, Yang AF, Meng H, Zhang JR (2005) In vitro induction of tetraploid plants from diploid Zizyphus jujube mill. $\mathrm{Cv}$. Zhan-hua. Plant Cell Rep 24:671-676

Gulia SK, Singh BP, Carter J, Griesbach RJ (2009) Daylily: botany, propagation, breeding. In: Janick J (ed) Horticultural reviews 35:193-220, doi:10.1002/9780470593776.ch3

Jackson RC, Casey J (1982) Cytogenetic analyses of autotetraploids: models and methods for triploids to octoploids. Am J Bot 69:487-501

Jakše M, Havey MJ, Bohanec B (2003) Chromosome doubling procedures of onion (Allium cepa L.) gynogenic embryos. Plant Cell Rep 21:905-910

Jaskani MJ, Khan IA (2000) Characterisation of interploid hybrids of Kinnow mandarin. Proc Int Soc Citri Cult $1: 165-166$

Jaskani MJ, Kwon SW, Kim DH (2005) Comparative study on vegetative, reproductive, and qualitative traits of seven diploid and tetraploid watermelon lines. Euphytica 145:259-268

Joshi P, Verma RC (2004) High-frequency production of colchicine induced autotetraploids in faba bean (Vicia faba L.). Cytologia 69:141-147

Kaensaksiri T, Soontornchainaksaeng P, Soonthornchareonnon N, Prathanturarug S (2011) Invitro induction of polyploidy in Centella asiatica (L.) Urban. Plant Cell Tiss Organ Cult 107:187-194

Levan A (1943) The pigment content of polyploid plants. Hereditas 29:255-268

Lysák MA, Doležel J (1998) Estimation of nuclear DNA content in Sesleria (Poaceae). Caryologia 51:123-132

Madlung A, Wendel JF (2013) Genetic and epigenetic aspects of polyploid evolution in plants. Cytogenet Genome Res 140:270-285

Marasek A, Okazaki K (2008) Analysis of introgression of the Tulipa fosteriana genome into Tulipa gesneriana using GISH and FISH. Euphytica 160:217-230

Marta AE, Camadro EL, Diaz-Ricci JC, Castagnaro AP (2004) Breeding barriers between the cultivated strawberry, Fragaria $\mathrm{x}$ ananassa, and related wild germplasm. Euphytica 136:139-150

Morejohn LC, Fosket DE (1984) Inhibition of plant microtubule polymerization in vitro by the phosphoric amide herbicide amiprophos methyl. Science 224:874-876

Murashige T, Skoog F (1962) Revised medium for rapid growth and bioassays, with tobacco tissue cultures. Physiol Plant 15:475-497

Niles WL, Quesenberry KH (1992) Pollen germination of rhizoma cv. Florigraze. Pinut Sci 19:105-107

Okazaki K, Kurimoto K, Miyajima I, Enami A, Mizuochi H, Matsumoto Y, Ohya $\mathrm{H}$ (2005) Induction of $2 n$ pollen in tulips by arresting meiotic process with nitrous oxide gas. Euphytica 143:101-114 
Osborn TC, Pires JC, Birchler JA, Auger DL, Chen ZJ, Lee H-S, Comai L, Madlung A, Doerge RW, Colot V, Martienssen RA (2003) Understanding mechanisms of novel gene expression in polyploids. Trends Genet 19:141-147

Parisod C, Holderegger R, Brochmann C (2010) Evolutionary consequences of autopolyploidy. New Phytol 186:5-17

Peck V, Peck R (1969) Breeding and improvement in tetraploid daylilies. Hemerocallis J 23(2):33-39

Petersen KK, Hagberg P, Kristiansen K (2003) Colchicine and oryzalin mediated chromosome doubling in different genotypes of Miscanthus sinensis. Plant Cell Tiss Organ Cult 73:137-146

Podwyszyńska M (2011) In vitro tetraploid induction in tulip. Acta Hort 961:391-396

Podwyszyńska M, Gabryszewska E, Jasiński A, Strycharczuk K (2010) Indukowanie tetraploidów liliowca w kulturach in vitro (In vitro tetraploid induction in daylily). Zeszyty Problemowe Postępów Nauk Rolniczych 551:263-274 (in Polish with English abstract)

Podwyszyńska M, Gabryszewska E, Jasiński A, Sochacki D (2011) Histogenic identification by cytological analysis of colchicine-induced polyploids of Hemerocallis. Acta Hort 886:245-250

Ramanna MS, Jacobsen E (2003) Relevance of sexual polyploidization for crop improvement-a review. Euphytica 133:3-8

Rogalska SM, Achrem M, Kalinka A (2007) Mechanizmy zmian genomowych i zmian w ekspresji genów w mieszańcowych poliploidach (Mechanisms of genome changes and gene expression in plant hybrid polyploids). Kosmos 56(3-4):421-433 (in Polish with English abstract)

Saito H, Mizunashi K, Tanaka S, Adachi Y, Nakano M (2003) Ploidy estimation in Hemerocallis species and cultivars by flow cytometry. Sci Hortic 97:185-192

Scott RJ, Tratt JL, Bolbol A (2013) Seed development in interploidy hybrids. In: Chen ZJ, Birchler JA (eds) Polyploid and hybrid genomics. Wiley, Hoboken, p 271

Simmonds NW (1995) Bananas. In: Smartt J, Simmonds NW (eds) Evolution of crop plants. Longman, Essex, pp 370-375

Śliwińska E (2008) Zastosowanie cytometrii przepływowej do oznaczania zawartości DNA u roślin (Estimation of DNA content in plants using flow cytometry. Postępy Biologii Komórki 35(Suppl 24):165-176 (in Polish with English abstract)

Snowdon RJ (2007) Cytogenetic and genome analysis in Brassica crops. Chromosome Res 15:85-95

Stanys V, Weckman A, Staniene G, Duchovskis P (2006) In vitro induction of polyploidy in Japanese quince (Chaenomeles japonica). Plant Cell Tiss Organ Cult 84:263-268

Stebbins GL (1984) Polyploidy and the distribution of arcticalpine flora: new evidence and a new approach. Bot Helv 94:1-13

Stupar RM, Bhaskar PB, Yandell BS, Rensink WA, Hart AL, Ouyang S, Veilleux RE, Busse JS, Erhardt RJ, Buel CR, Jiang J (2007) Phenotypic and transcriptomic changes associated with potato autopolyploidisation. Genetics 176:2055-2067

Sun Q, Sun H, Bell RL, Li H, Xin L (2011) Variation of phenotype, ploidy level, and organic potential of in vitro regenerated polyploids of Pyrus communis. Plant Cell Tiss Organ Cult 107:131-140

Trojak-Goluch A, Skomra U (2013) Artificially induced polyploidization in Humulus lupulus L. and its effect on morphological and chemical traits. Breed Sci 63:393-399. doi:10.1270/jsbbs.63.393

Väinölä A (2000) Polyploidisation and early screening of Rhododendron hybrids. Euphytica 112:239-244

Van Tuyl JM, Meijer B, Van Diën MP (1992) The use of oryzalin as an alternative for colchicine in vitro chromosome doubling of Lilium and Nerine. Acta Hort 325:625-630

Webster AD (1996) Cherry rootstock evaluation at East Malling. Acta Hort 410:247-255

Wojciechowicz MK (2009) Anti-mitotic agents in Salix viminalis polyploid plant induction. Acta Biol Crac Ser Botanica 51(Suppl 1):26

Younis A, Hwang YJ, Lim KB (2014) Exploitation of induced 2n-gametes for plant breeding. Plant Cell Rep 33:215-223

Zhang C, Cao DM, Zhang XC, Kang LF, Duan JJ, Ma XL, Yan GJ, Wang YS (2013) Ploidy variation in Hemerocallis spp. and the implications on daylily breeding. Acta Hort 977:197-203 